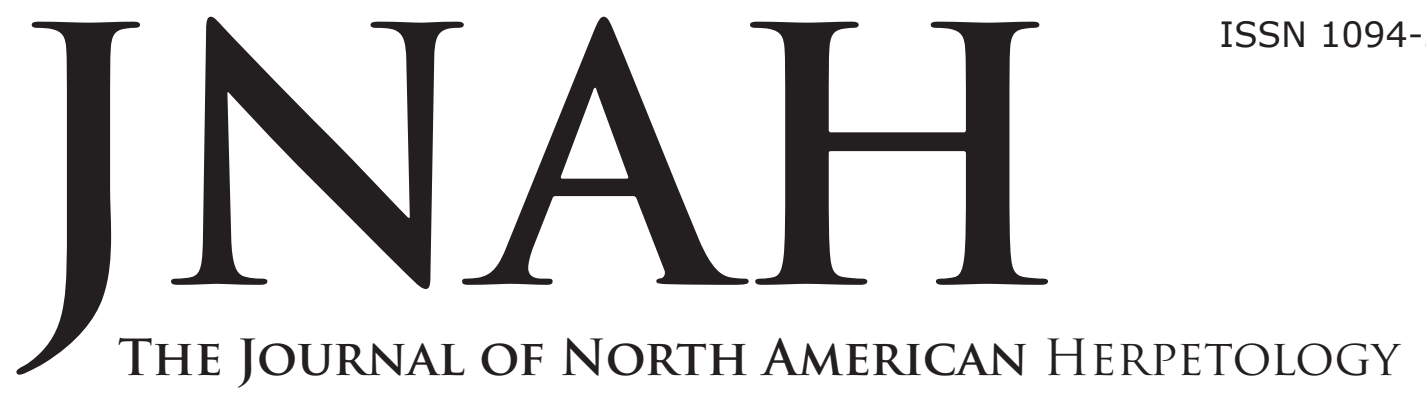

Volume 2016, Number 1

5 July 2016

jnah.cnah.org

\title{
AMPHIBIAN RESPONSE \\ TO A LARGE-SCALE HABITAT RESTORATION IN THE PRAIRIE POTHOLE REGION
}

\author{
ROCHELLE M. STILES ${ }^{1}$, CHRIS H. LA RUE², MICHAEL J. HAWKINS ${ }^{2}$, \\ WILLIAM A. MITCHELL ${ }^{1}$, AND MICHAEL J. LANNOO ${ }^{3}$
}

\author{
${ }^{1}$ Department of Biology, Indiana State University, Terre Haute, Indiana, USA \\ ${ }^{2}$ Iowa Department of Natural Resources, Spirit Lake, Iowa, USA \\ ${ }^{3}$ Terre Haute Center for Medical Education, Indiana University School of Medicine, Terre \\ Haute, Indiana, USA; Corresponding author. E-mail: mlannoo@iupui.edu
}

\begin{abstract}
Over the next half-century, scientists anticipate that nearly one third of the currently recognized 7,450 amphibian species will become extinct. Many organizations have responded to the challenge of conserving amphibian biodiversity, some indirectly. Under the auspices of the Iowa Great Lakes Management Plan, the United States Fish and Wildlife Service, Department of Natural Resources, and their partners have been implementing habitat restoration efforts designed to protect water quality, provide recreational opportunities, and benefit wildlife at the regional level. With this program, over 130 wetlands have been created in the past 30 years on recently purchased public lands-one of the largest wetland restoration projects conducted in the Prairie Pothole Region of the Great Plains. While amphibians were not the main target of these restorations, we show that in response, 121 new breeding populations of native Northern Leopard Frogs (Lithobates pipiens; $n=80$ ) and Eastern Tiger Salamanders (Ambystoma tigrinum; $n=41$ ) have been established; in addition, we found 19 populations of non-native American Bullfrogs (L. catesbeianus). Using the program PRESENCE, we show that leopard frog occupancy was greatest in newer ( $<18$ years old), intermediate-sized wetlands, and that tiger salamander occupancy was greatest in small wetlands without fish and larval bullfrogs. These data imply that because native amphibians responded positively to these newly established wetlands, habitat availability has likely been a factor in limiting population numbers. Further, these data suggest the presence of fishes and introduced bullfrogs interferes with the ability of tiger salamanders to colonize restored wetlands.
\end{abstract}

Key words: Ambystoma tigrinum; American Bullfrog; Eastern Tiger Salamander; Lithobates catesbeianus; Lithobates pipiens; Northern Leopard Frog

\section{INTRODUCTION}

Amphibians are in global decline (Stuart et al., 2004; Gascon et al., 2007; Wake and Vredenburg, 2008; Alroy, 2015), and over the next few decades scientists expect nearly one third of the currently recognized 7,450 amphibian species to become extinct (Norris, 2007; Collins and Crump, 2009; AmphibiaWeb, 2015). This news is grim, but occasionally amphibian conservation efforts get a boost from an unintended source. Here we describe one example-occurring at a regional level in the United States-of habitat restoration efforts with non-amphibian targeted goals benefitting native species of amphibians.
Historically, prairie pothole wetlands were a dominant landscape feature of the northern Great Plains. This Prairie Pothole Region represented one of the largest wetland assemblages in the world, covering more than $777,000 \mathrm{~km}^{2}$ of the north-central United States and Canadian Prairie provinces (Mann, 1974; van der Valk, 2005). The Okoboji lakes region of northwestern Iowa occupies the southeastern corner of the Prairie Pothole Region (Nicollet, 1843; Galatowitsch and van der Valk, 1994). With EuroAmerican settlement, beginning in the mid-nineteenth century, an estimated $98 \%$ of these wetlands were drained as the land was being prepared for agriculture (Galatowitsch and van der Valk, 1994; Lan- 
noo, 1996). More recently, however, in segments of the Prairie Pothole Region this trend has been reversed. Over the past three decades, the United States Fish and Wild-
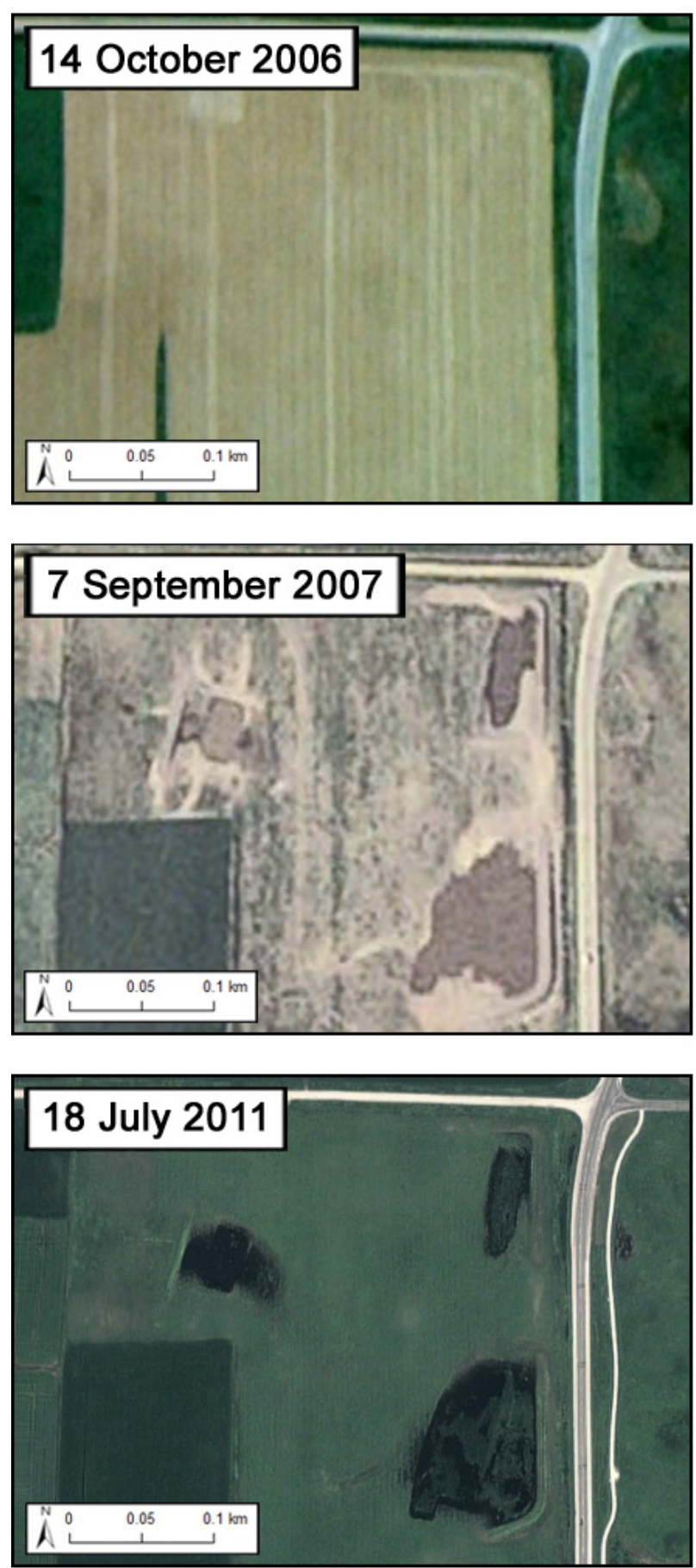

Figure 1. Example of wetland restorations in previously cultivated croplands. From the swamp busting efforts of the early twentieth century until the fall of 2006, this field was used for agriculture. Then in 2007, under the Iowa Great Lakes Management Plan, collaborators purchased this land, broke tile lines, and allowed these basins to naturally refill. These wetlands have held water since and during our 2012 survey supported breeding Northern Leopard Frogs and Eastern Tiger Salamanders. Imagery: United States Department of Agriculture, Farm Service Agency, National Agriculture Imagery Program, September 2011. life Service (USFWS), through the U.S. Federal Migratory Bird Hunting and Conservation (Duck) Stamp Program's Waterfowl Production Area Initiative, the Iowa Department of Natural Resources (Iowa DNR) Wildlife Management Areas program, and their many partners, including Ducks Unlimited, Pheasants Forever, and dozens of other private, public, and state organizations, have implemented public land and wetland restoration efforts designed to protect water quality, provide recreational opportunities, and benefit wildlife. The Iowa Great Lakes Management Plan formalized this effort and prioritized wetland restorations and other water quality improvement projects (Evelsizer and Johnson, 2010). Towards this end, over 130 wetlands ranging in size and hydroperiod from small ephemeral basins to large permanent wetlands have been built on recently purchased public lands, spanning nearly $80 \mathrm{~km}^{2}$ in Dickinson County alone (Iowa DNR, 2014). Within this region, basins targeted for restoration were chosen based on watershed size, the potential to stop erosion, and the proximity of existing wetlands (C.H. La Rue, unpublished data).

With the creation of wetlands in the Okoboji region, faculty at the Iowa Lakeside Laboratory noticed an increase in native amphibian numbers (mostly anecdotally, but see Lannoo et al., 1994; Lannoo, 1996, 2012b). To evaluate these newly restored wetlands as breeding habitat for Northern Leopard Frogs (Lithobates pipiens) and Eastern Tiger Salamanders (Ambystoma tigrinum), we identified and surveyed 130 basins for larval native amphibians; 118 of these held water and were sampled. We were interested first in the presence of native amphibian species in these restorations. We were also curious about the relationships of these species to the physical characteristics of these wetlands, to each other, and to the presence of invasive American Bullfrogs ( $L$. catesbeianus) as well as fishes, which are often illegally introduced into these wetlands by bait dealers (M.J. Hawkins and M.J. Lannoo, unpublished data). While our work follows similar studies exploring amphibian colonization of created wetlands (e.g., Lehtinen and Galatowitsch, 2001; Zimmer et al., 2002; Petranka et al., 2007; Shulse et al., 2010), our study is unique in being geographically broad, which is consistent with Templeton et al.'s (1995) suggestion for an adequate regional sample design.

\section{MATERIALS AND METHODS}

Study Area - The Okoboji region of northwestern Iowa is located in Dickinson County (lat $43^{\circ} \mathrm{N}$, long $95^{\circ} \mathrm{W}$ ). Okoboji spans approximately $325 \mathrm{~km}^{2}$ and is notable for containing the state's highest concentration of wetlands (Lannoo, 1996). Wetlands in Okoboji are potholes ranging in size from small seasonal basins to large permanent wetlands situated in surrounding tallgrass prairie (Anonymous, 1906; Lannoo, 1996, 1998). The majority $(85-95 \%)$ of wetlands we sampled were restored by breaking agricultural tile lines allowing the kettle morainic topography to revert to its historical hydrologic condition (Figure 1); therefore, these wetlands were restorations, not created de novo as, for example, with mitigation basins. Remaining wetlands were created in upland habitats by constructing berms, with or without excavation, on the downgrade side of drainages (C.H. La Rue, unpublished data).

Study Species - Amphibians in the Okoboji region include native Northern Leopard Frogs, Eastern Tiger Salamanders, American Toads (Anaxyrus americanus), and Western Chorus Frogs (Pseudacris triseriata), and 
non-native American Bullfrogs (Lannoo et al., 1994). All of these species have aquatic larval stages. We focused primarily on surveying the larvae of native Northern Leopard Frogs and Eastern Tiger Salamanders, and secondarily on surveying non-native American Bullfrogs, since these animals are present in wetlands during mid-summer (Lannoo et al., 1994; Lannoo, 1996). In contrast, Western Chorus Frog and American Toad tadpoles metamorphose too early to be surveyed completely during the several weeks it takes to sample a large number of wetlands.

We had a small crew; therefore we needed a rapid, reliable, unbiased sampling technique that could establish occupancy of a large number of wetlands in a short period of time. Given that thick, mid-summer macrophyte growth precluded seining and dip netting as effective, unbiased sampling options, we used conventional, unbaited, aquatic funnel traps to sample for tadpoles and salamander larvae (Lannoo et al., 1994; Shaffer et al., 1994; Dodd, 2010). Our surveys began on 5 June, when animals were large enough to be contained by the mesh of our traps, and ended on 3 July, before larvae metamorphosed and exited wetlands; sampling outside this window risked underestimating annual occupancy.

Sampling Design - Our goal was to establish a regional pattern of amphibian occupancy in response to wetland restorations; therefore we needed to sample a large number of wetlands across the landscape. To do this, we first identified wetlands visible on satellite photography (Google Earth version 6.2) and accessible by being publicly owned (Federal Waterfowl Production Areas [WPAs] managed by the Iowa DNR). In each wetland, we set three fine-mesh traps (mesh size $=2 \times 4 \mathrm{~mm}$, internal funnel opening $=60 \mathrm{~mm}$ ) and three coarse-mesh traps (mesh size $=10 \times 10 \mathrm{~mm}$, internal funnel opening $=127$ $\mathrm{mm}$; manufactured by American Maple Inc., Gardena, CA, U.S.A., [Shaffer et al., 1994; Dodd, 2010]) in the shallows. We oriented traps obliquely to the shoreline, spaced them at 2-m intervals, and alternated small- and medium-mesh trap types. Traps were checked every 24 hours for the presence of Northern Leopard Frog and Eastern Tiger Salamander larvae. Because we faced a limited sampling window due to the impending metamorphosis of Northern Leopard Frogs (aquatic larval stage <7 weeks; [Lannoo, 1996]) and we wished to sample a large numbers of wetlands, we adopted the removal sampling design of MacKenzie and Royle (2005); that is, we removed all traps once both native species (Northern Leopard Frogs and Eastern Tiger Salamanders) were captured. If either species was absent, we left the traps for a total of 72 hours (three sampling periods) and then removed them; species not captured were considered absent. Although not the primary focus of this project, we also noted captured American Bullfrogs and fishes during each check, since these species are known to have negative effects on native amphibians (Schwalbe and Rosen, 1988; Galatowitsch and van der Valk, 1994; Hecnar and M'Closkey, 1997; Knapp and Matthews, 2000; Zimmer et al., 2002; Casper and Hendricks, 2005; Pope, 2008; Herwig et al., 2013). For each site sampled, we determined wetland age based on restoration dates and calculated surface area using minimum convex polygons contained in the Iowa DNR database. We adjusted polygons using ESRI ArcMap 10.0 (ESRI, 2011) to reflect the water levels during the study.

Funnel trapping has been shown to be an effective technique for the amphibian species we sampled (Korfel et al., 2010). Nevertheless, we wished to have a sec- ond assessment of detectability, therefore, we randomly chose ten wetlands previously sampled using our primary funnel trap design, and re-sampled them by seining.

Statistical Analysis - We analyzed presence-absence data using single-season occupancy models available through the program PRESENCE 5.5 (MacKenzie et al., 2004, 2006; Hines and MacKenzie, 2013). This type of modeling does not require equal effort across all sites and thus is ideal for a removal design (MacKenzie et al., 2002, 2004, 2006; Rota et al., 2011). Removal sampling is effective when "the main piece of information required is confirmation that the target species is present at a site" (MacKenzie et al., 2006). In addition, trap removal after species are detected is more efficient than a standard design when estimating occupancy of a large number of sites, but species must be detected with certainty. Using this technique, probability estimates of "false absences"-situations in which animals will go undetected when they are actually present-cannot be calculated with the highest degree of accuracy (MacKenzie and Royle, 2005; MacKenzie et al., 2006). Thus, using this technique alone offers a tradeoff between calculating detection probabilities and surveying a large number of sites in a short timeframe. Here we chose to sample a large number of sites but offset lower detection probabilities by resampling a subset of these wetlands using an alternative technique (seining; Shaffer et al., 1994; Dodd, 2010).

For our analyses, we considered all combinations of the following covariates: wetland surface area, wetland age, American Bullfrog detection, and fish detection. We normalized wetland surface areas and categorized wetland ages as "young" ( $<18$ years) or "old" ( $\geq 18$ years). We included captures of American Bullfrogs and fishes only from the first sampled day, making the survey effort for these species consistent for each wetland. We did not consider the presence of American Bullfrogs and fishes when deciding to pull the traps, since we were primarily interested in the response of native amphibian species to the wetland restorations. (i.e., Given the number of wetlands we wished to sample and the time constraints presented by impending metamorphosis, including bullfrogs and fishes in our main sample design would have meant restricting the number of wetlands sampled.) To determine which covariates explained the most variation in occupancy, we calculated a model-averaged measure or a summed model weight for each covariate (see Burnham and Anderson, 2002; MacKenzie, 2006). We present occupancy values first as naïve (i.e., the number of sites with positive detection divided by the total number of sites), then as model estimated (i.e., naïve value adjusted with the detectability estimate). We also calculated the probability of detecting leopard frogs or tiger salamanders at least once, given our techniques, during surveys of occupied sites (detection probabilities; Donovan and Hines, 2007).

We used PRESENCE single-season two-species occupancy models (Mackenzie et al., 2004, 2006) to investigate relationships among amphibian species. We calculated a species interaction factor (SIF) for two species using phi/delta model parameters. A SIF value greater than one suggests association between two species, while a SIF value less than one suggests disassociation. A SIF value equal to one signifies neither association nor disassociation but rather independent co-occurrence (for a further description see MacKenzie et al., 2004, 2006). SIF values are given with $95 \%$ confidence intervals.

To determine the influence of wetland age on species 
Table 1. Amphibian and fish occurrence in restored wetlands in northwestern Iowa sampled in 2012. Rows are grouped based on single species (or fishes, collectively), co-occurrences, and multiple occurrences. Abbreviations: $\mathrm{BF}=$ American Bullfrogs (Lithobates catesbeianus); LF = Northern Leopard Frogs ( . pipiens); TS = Eastern Tiger Salamanders (Ambystoma tigrinum); Unoccupied = wetlands unoccupied by native amphibians.

\begin{tabular}{lccc}
\hline \hline & $\begin{array}{c}\text { Number } \\
\text { of } \\
\text { Wetlands }\end{array}$ & $\begin{array}{c}\text { Percentage } \\
\text { of All } \\
\text { Wetlands }\end{array}$ & $\begin{array}{c}\text { Percentage of Native } \\
\text { Amphibian-occupied } \\
\text { Wetlands }\end{array}$ \\
\hline LF & 80 & 68 & 96 \\
TS & 41 & 35 & 49 \\
BF & 19 & 16 & 10 \\
Fishes & 44 & 37 & 27 \\
LF+TS & 38 & 32 & 46 \\
LF+Fishes & 21 & 18 & 25 \\
BF+Fishes & 15 & 13 & 6 \\
LF+BF & 8 & 7 & 10 \\
TS+Fishes & 3 & 3 & 4 \\
TS+BF & 0 & 0 & 0 \\
LF+BF+Fishes & 5 & 5 & 6 \\
LF+TS+Fishes & 2 & 2 & 2 \\
LF+TS+BF & 0 & 0 & 0 \\
LF+TS+BF+Fishes & 0 & 0 & 0 \\
TS+BF+Fishes & 0 & 30 & 0 \\
Unoccupied & 35 & & 0 \\
\hline \hline
\end{tabular}

composition, we used Chi-Square Goodness of Fit tests calculated in SPSS version 14.0 (SPSS, 2005). For this analysis, we grouped wetlands into categories based on years since restoration as follows: $0-5,6-8,9-10,11-$ $14,15-17$, and $\geq 18$; numbers of wetlands were roughly equal within each category, facilitating comparison. Grouping was necessary since the exact ages of a subset of wetlands in the $\geq 18$ category were unknown. We later clumped wetlands into two age categories, "young" ( $<18$ years) or "old" ( $\geq 18$ years), based on preliminary ChiSquare test results. To explore the influence of wetland size on species composition, we used a one-way Analysis of Variance (ANOVA) and Tukey's Honestly Significant Difference (HSD) post-hoc test on $\log _{10}$ transformed data. Surface areas are reported as means with $95 \%$ confidence intervals.

\section{RESULTS}

Amphibians responded favorably to habitats created under the Iowa Great Lakes Watershed Management Plan (Table 1). Of the 118 sampled wetlands, 98 (83\%) supported amphibians. Within these occupied wetlands, 80 (68\% of the total sampled, naïve occupancy; $69 \%$ model estimated occupancy; $91 \%$ estimated detectability) supported native Northern Leopard Frogs and 41 (35\% naïve occupancy; $40 \%$ model estimated occupancy; $83 \%$ estimated detectability) supported native Eastern Tiger Salamanders. Nineteen wetlands (16\% naïve occupancy; $19 \%$ model estimated occupancy; $61 \%$ estimated detectability) supported introduced American Bullfrogs. Thirty-five wetlands $(30 \%)$ were unoccupied by native amphibians. Thirty-two wetlands occupied by native amphibians held fishes (Table 1; Figure 2). Fish species captured were Green Sunfish (Lepomis cyanellus), Bluegill (L. macrochirus), Black Bullhead (Ameiurus melas), Brown Bullhead ( $A$. nebulosus), Common Shiner (Luxilus cornutus), Yellow Perch (Perca flavescens), Shortnose Gar (Lepisosteus platostomus), Fathead Minnow (Pimephales promelas), and Brook Stickleback (Culaea inconstans).

Several abiotic factors appeared to influence the pres- ence of individual amphibian species. The best-fit single-season models for both targeted native amphibians suggest that the size of the wetland basin influenced species present (summed model weights: tiger salamanders $=98 \%$, leopard frogs $=100 \%$; Table 2). Eastern Tiger Salamanders on average occupied wetlands with the smallest surface areas $\left(6,700 \pm 2,400 \mathrm{~m}^{2}\right.$; mean $\pm 95 \%$ confidence interval), while Northern Leopard Frogs occupied wetlands with intermediate surface areas $(11,500$ $\pm 2,900 \mathrm{~m}^{2}$ ). Non-targeted American Bullfrogs and fishes on average occupied the largest of the reconstructed wetlands (bullfrogs $=37,200 \pm 18,400 \mathrm{~m}^{2}$; fishes $=$ $\left.30,100 \pm 9,200 \mathrm{~m}^{2}\right)$. Wetlands unoccupied by native amphibians $\left(34,800 \pm 11,700 \mathrm{~m}^{2}\right)$ were on average larger than wetlands occupied by native amphibians $(11,500 \pm$ $2,800 \mathrm{~m}^{2}$; ANOVA, $F[1,116]=12.0, p<0.001$; Figure $3)$. The mean surface area for all sampled wetlands was $18,400 \pm 4,400 \mathrm{~m}^{2}$.

Single-season models indicate that wetland age predicts occupancy of Northern Leopard Frogs but not necessarily Eastern Tiger Salamanders (summed model weights: leopard frogs $=96 \%$, tiger salamanders $=49 \%$; Table 2 ). Northern Leopard Frogs disproportionately occupied the most recently restored wetlands, while Eastern Tiger Salamanders showed no preferences for wetlands of particular ages.

Biotic factors also influenced the presence of particular amphibian species. Single-season models suggest that American Bullfrog and fish presence appears to reduce the presence of Eastern Tiger Salamanders more than Northern Leopard Frogs (bullfrog summed model weights: tiger salamanders $=87 \%$, leopard frogs $=$ $42 \%$; fish summed model weights: tiger salamanders $=$ $94 \%$, leopard frogs $=28 \%$; Tables 1 and 2 ). For example, among the 118 wetlands sampled we did not detect Eastern Tiger Salamander larvae in wetlands with American Bullfrog tadpoles (SIF < 0.001; Table 1; Figs. 4 and 5). Other species interactions were less definitive (Table 1; Figure 5). Northern Leopard Frogs and Eastern Tiger Salamanders co-occurred more often than expected (assuming independent co-occupancy; SIF $=1.23$, 
Table 2. Amphibian occupancy modeling. Results from single-season models constructed with the program PRESENCE explaining the factors influencing occupancy of Northern Leopard Frogs (Lithobates pipiens) and Eastern Tiger Salamanders (Ambystoma tigrinum). We considered all combinations of the following covariates: SA = wetland surface area; Age = wetland age; BF = American Bullfrog ( $L$. catesbeianus) detection; and Fish = fish detection. We normalized wetland surface areas and categorized wetland ages as "young" (< 18 years) or "old" ( $\geq 18$ years). Here, we include models with $\omega_{i}>0.001$ and with constant occupancy and detection probability $[\psi(),. p()$.$] . Abbreviations: \psi=$ occupancy; $\mathrm{p}=$ detection; $\mathrm{K}=$ number of parameters; AIC $=$ Akaike information criterion; $\omega_{i}=$ Akaike weight; $\mathrm{L}=$ model likelihood; Global = SA+Age+BF+Fish

\begin{tabular}{|c|c|c|c|c|c|}
\hline Species & Model & K & $\triangle \mathrm{AIC}$ & $\omega_{i}$ & $-2 \log (L)$ \\
\hline \multirow[t]{5}{*}{ Lithobates pipiens } & $\psi(\mathrm{SA}+\mathrm{Age}), \mathrm{p}()$. & 4 & 0.00 & 0.4087 & 218.07 \\
\hline & $\psi(\mathrm{SA}+\mathrm{Age}+\mathrm{BF}), \mathrm{p}()$. & 5 & 0.57 & 0.3074 & 216.64 \\
\hline & $\psi($ SA + Age + Fish $), p()$. & 5 & 1.81 & 0.1654 & 217.88 \\
\hline & $\psi($ Global $), \mathrm{p}()$. & 6 & 2.56 & 0.1136 & 216.63 \\
\hline & $\psi(),. \mathrm{p}()$. & 2 & 20.34 & $<0.0001$ & 242.41 \\
\hline \multirow[t]{10}{*}{ Ambystoma tigrinum } & $\psi(\mathrm{SA}+\mathrm{Fish}+\mathrm{BF}), \mathrm{p}()$. & 4 & 0.00 & 0.4493 & 162.01 \\
\hline & $\psi($ Global $), \mathrm{p}()$. & 6 & 0.51 & 0.3482 & 158.52 \\
\hline & $\psi(\mathrm{SA}+$ Fish+Age $), \mathrm{p}()$. & 5 & 3.49 & 0.0785 & 163.50 \\
\hline & $\psi(\mathrm{SA}+\mathrm{BF}+\mathrm{Age}), \mathrm{p}()$. & 5 & 4.01 & 0.0605 & 164.02 \\
\hline & $\psi(\mathrm{SA}+\mathrm{Fish}), \mathrm{p}()$. & 3 & 4.63 & 0.0444 & 168.64 \\
\hline & $\psi($ Fish $+B F), p()$. & 3 & 7.40 & 0.0111 & 171.41 \\
\hline & $\psi($ Fish + BF+Age $), p()$. & 5 & 9.41 & 0.0041 & 169.42 \\
\hline & $\psi(\mathrm{SA}+\mathrm{BF}), \mathrm{p}()$. & 3 & 11.21 & 0.0017 & 175.22 \\
\hline & $\psi(\mathrm{SA}+\mathrm{Age}), \mathrm{p}()$. & 2 & 11.91 & 0.0012 & 173.93 \\
\hline & $\psi(),. p()$. & 2 & 34.58 & $<0.0001$ & 200.59 \\
\hline
\end{tabular}

1.08-1.40; Table 1), while Northern Leopard Frogs and American Bullfrogs co-occurred less often than expected $(\mathrm{SIF}=0.61,0.38-0.98 ;$ Table 1$)$.

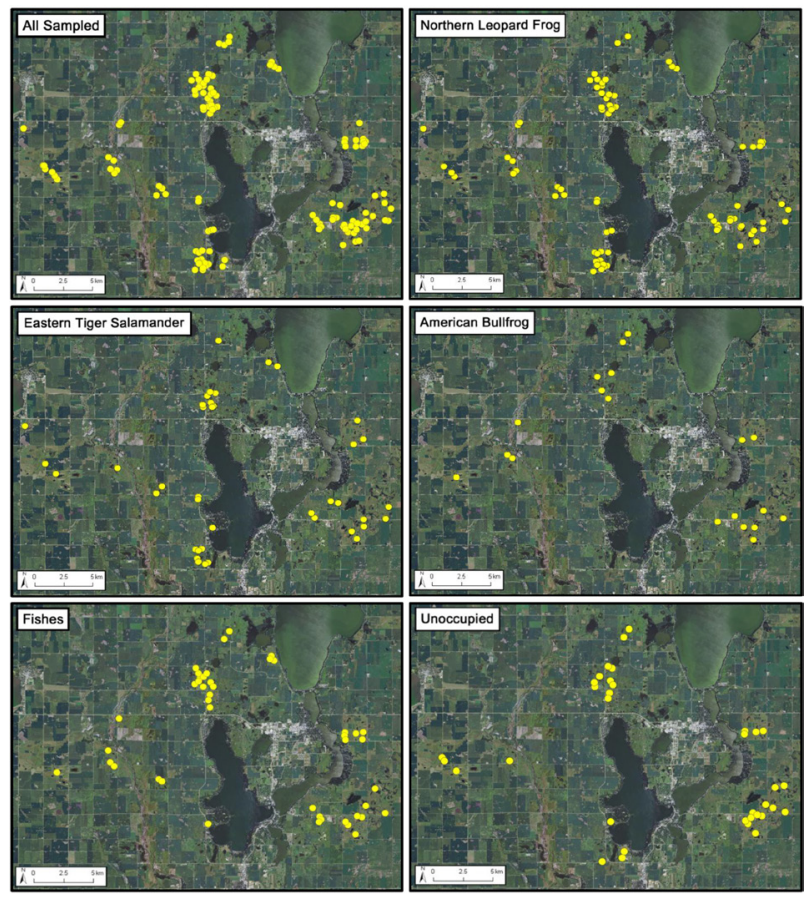

Figure 2. Locations of all sampled wetlands and wetlands occupied by species and taxa. Of 118 sampled wetlands, amphibian occupancy varied as follows: Northern Leopard Frogs (Lithobates pipiens; $n=80$ ), Eastern Tiger Salamanders (Ambystoma tigrinum; $n=41$ ), American Bullfrogs (L. catesbeianus; $n=19$ ), fishes (Green Sunfish, Lepomis cyanellus; Bluegill, L. macrochirus; Black Bullhead, Ameiurus melas; Brown Bullhead, A. nebulosus; Common Shiner, Luxilus cornutus; Yellow Perch, Perca flavescens; Shortnose Gar, Lepisosteus platostomus; Fathead Minnow, Pimephales promelas; and Brook Stickleback, Culaea inconstans; $n=44)$, and wetlands unoccupied by native amphibians $(n=35)$. Imagery: United States Department of Agriculture, Farm Service Agency, National Agriculture Imagery Program, September 2011.
To compare detectability across sampling techniques, we re-sampled wetlands previously funnel trapped by seining. In nine of these wetlands, amphibian species obtained were identical to the species captured in our funnel traps. In the tenth basin, seining (macrophyte density limited seine haul length) missed tiger salamander larvae, which were detected using funnel traps.

\section{DISCUSSION}

Historical Perspective - In the Okoboji region, Northern Leopard Frogs were abundant and widespread during the early 1900 s. During this time, they were commercially harvested, with an estimated 20 million adults collected and shipped annually to eastern restaurants (Anonymous, 1906; Barrett, 1964). This industry was sustainable until the massive swamp busting efforts of the early twentieth century destroyed most of their breeding habitat (Lannoo, 1996). More recent surveys

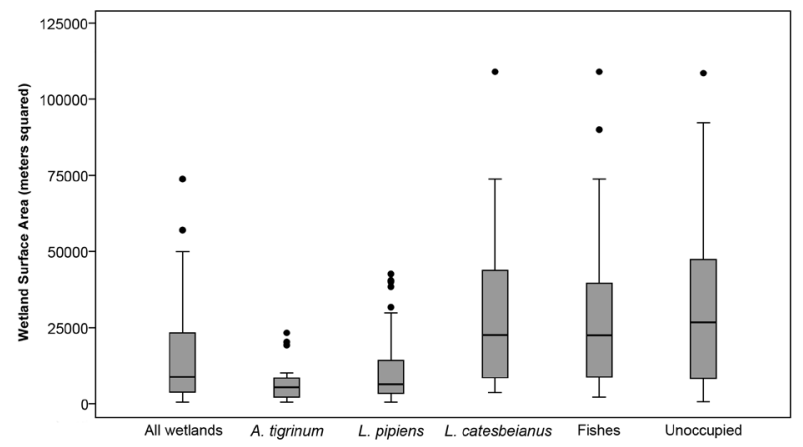

Figure 3. Occupancy and restored wetland sizes. Native amphibian species occupied restored wetlands of different sizes, as follows: Eastern Tiger Salamanders (Ambystoma tigrinum) occupied the smallest wetlands and Northern Leopard Frogs (Lithobates pipiens) occupied intermediate-sized wetlands. American Bullfrogs (L. catesbeianus) and fishes occupied the largest restored wetlands. Similarly, wetlands unoccupied by native amphibians were on average larger than wetlands occupied by native amphibians. Boxes depict the 25th-75th percentiles; bars are 1.5 interquartile ranges of the maximum box value or depict the maximum or minimum data values given narrower data ranges. Outliers within 3 interquartile ranges are included. 
have indicated that leopard frogs continue to be the most numerous amphibian species in the region (Lannoo et al., 1994; Lannoo, 1996). Our data suggest Northern Leopard Frogs responded most robustly to Okoboji wetland restorations, with 80 new breeding populations documented ( $91 \%$ estimated detectability; Table 1; Figure 2 ), is consistent with these historical data.

Eastern Tiger Salamanders were also relatively common in this region, and our data here (41 wetlands occupied; $83 \%$ estimated detectability; Table 1; Figure 2 ) suggest they have responded well to wetland restorations. This result is encouraging, given that the morphological plasticity confers special conservation consideration to tiger salamander larvae in this region. Eastern Tiger Salamander larvae in Okoboji develop cannibal morphs - characterized by unusually large heads and hypertrophied teeth-with a frequency that is uncommon in more eastern populations (Lannoo and Bachmann, 1984; Lannoo, 1996).

American Bullfrogs were introduced by the state of Iowa officials in the late 1960 s to provide recreational opportunities for fishing license holders (Lannoo, 1996). Adult American Bullfrogs are known to eat almost any animal smaller than themselves, including native frog and salamander species (Schwalbe and Rosen, 1988; Galatowitsch and van der Valk, 1994; Casper and Hendricks, 2005). Their presence in 19 of the 118 restored wetlands (with $61 \%$ estimated detectability; Table 1; Figure 2) we sampled blunts the beneficial impacts of these restorations on native amphibian populations.

Fishes have probably always been a component of large, permanent Okoboji wetlands, and we found a remarkable diversity of fishes in the 32 wetlands that supported them, ranging phylogenetically from gar, through minnows, bullheads, and sticklebacks, to sunfish and perch. Predatory fishes are known to feed on the larvae of ranid frogs and Eastern Tiger Salamanders (Lannoo, 1996; Hecnar and M'Closkey, 1997; Knapp and Matthews, 2000; Walston and Mullin, 2007), but bullfrog larvae are generally not part of the preferred diet of fishes (Evenson and Kruse, 1982).

Comparison with Other Studies - There is general agreement that wetland creation enhances breeding

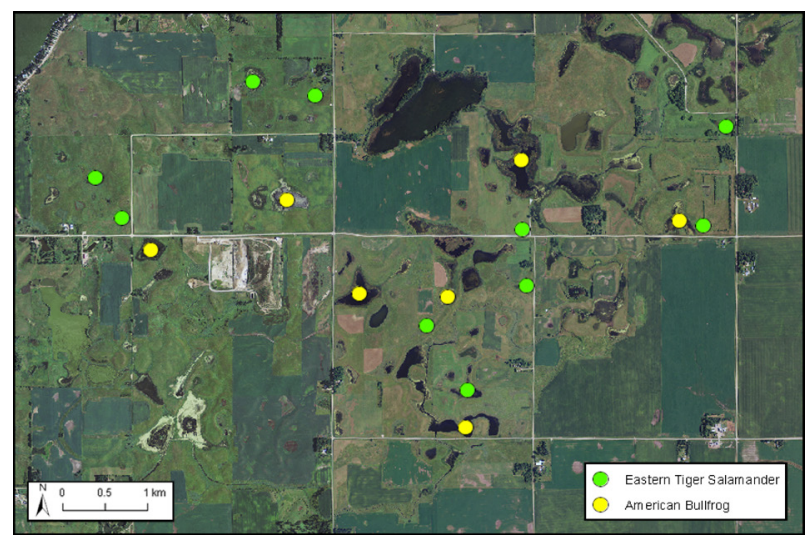

Figure 4. Disassociation between Eastern Tiger Salamanders and American Bullfrogs. In our survey, larvae of Eastern Tiger Salamanders (Ambystoma tigrinum) and American Bullfrogs (Lithobates catesbeianus) were never syntopic $(n=118)$. Here we show one example from the Spring Run Complex, of occupancy by Eastern Tiger Salamanders $(n=10)$ and American Bullfrogs $(n=7)$. Imagery: United States Department of Agriculture, Farm Service Agency, National Agriculture Imagery Program, September 2011. habitat for native amphibians (e.g., Rosen and Schwalbe, 1998; Petranka et al., 2003a, b; Balcombe et al., 2005; Liner et al., 2008; Korfel et al., 2010; but see Porej and Hetherington, 2005), although the response to these new habitats varies with ecological factors such as wetland size (i.e., hydrology; Weller, 1995; Skelly et al., 1999; Lehtinen and Galatowitsch, 2001; Vasconcelos and Calhoun, 2006; Constantino et al., 2011), vegetation (Pechmann et al., 2001; Shulse et al., 2010), proximity to established breeding wetlands (Lehtinen et al., 1999; Pope et al., 2000; Semlitsch, 2000; Lehtinen and Galatowitsch, 2001; Petranka et al., 2004; Constantino et al., 2011), upland habitat quality (Kolozsvary and Swihart, 1999; Vasconcelos and Calhoun, 2004), and the presence of fishes (Lannoo, 1996; Hecnar and M'Closkey, 1997; Knapp and Matthews, 2000; Snodgrass et al., 2000; Walston and Mullin, 2007; Shulse et al., 2010; Constantino et al., 2011). The amphibian response to wetland creation also varies by species (Shulse et al., 2010; Mushet, 2012a).

The number and range of wetlands we sampled allowed us to tease out the effects of wetland size, and the presence of fishes and American Bullfrogs, on native amphibian populations. For example, size of wetland basins influenced the presence of native amphibians in species-specific ways: Northern Leopard Frogs occupied intermediate-sized wetlands while Eastern Tiger Salamanders occupied the smallest-sized wetlands we sampled (Table 2; Figure 3). Non-native American Bullfrogs occupied the largest wetlands in our sample (Table 2).

The negative impact of fishes and American Bullfrogs on native amphibian species can be large (Hayes and Jennings, 1986; Bradford, 1989; Joseph et al., 2010; Herwig et al., 2013). Here we show species-specific impacts, with Eastern Tiger Salamanders affected far more than Northern Leopard Frogs (Tables 1 and 2; Figure 5). We found only three wetlands with fishes that supported Eastern Tiger Salamanders and none that supported American Bullfrogs and Eastern Tiger Salamanders (Table 1). In contrast, 21 wetlands supported fishes and Northern Leopard Frogs, 15 wetlands supported American Bullfrogs and Northern Leopard Frogs (Table 1). This result agrees with the conclusion of Adams et al. (2011),

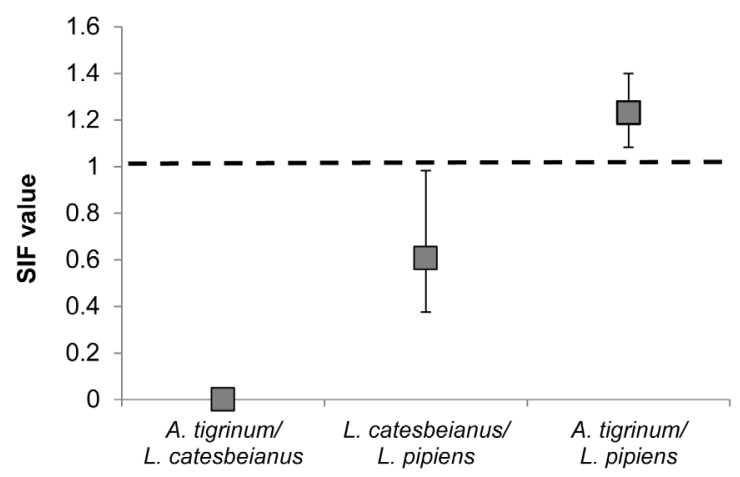

Figure 5. Interactions between amphibian species. Species interactions among Okoboji amphibians were never neutral. Here, the dotted line represents a Species Interaction Factor (SIF) value of one, reflecting independent co-occurrence. Eastern Tiger Salamanders (Ambystoma tigrinum) and American Bullfrogs (Lithobates catesbeianus) were never found co-existing. American Bullfrogs and Northern Leopard Frogs (L. pipiens) also disassociated, but not as intensely. Eastern Tiger Salamanders and Northern Leopard Frogs weakly associated with one another. These data do not address the causes of these relationships. Bars indicate $95 \%$ confidence interval. 
who found that the presence of non-native bullfrogs had little effect on the occupancy of wetlands by native western ranid species. The best supported single-season model explaining Northern Leopard Frog occupancy included wetland surface area and age, while the best supported model explaining Eastern Tiger Salamander occupancy included surface area as well as the presence of fishes and American Bullfrogs (Table 2).

In addition to wetland size and the presence of potential predators and competitors, we found a difference in species occupancy based on wetland age: Eastern Tiger Salamanders showed no bias, while Northern Leopard Frogs occupied the most recent restorations. Wetland age has been shown to influence amphibian species present, especially in new restorations. For example, Vasconcelos and Calhoun (2006) recommended a monitoring period of more than three years following wetland construction to determine reproductive success of targeted species. Consistent with this recommendation, Snodgrass et al. (2000) found that 8-10 year old wetland restorations supported the most diverse amphibian assemblages.

Most previous studies examining amphibian colonization of created wetlands differed from ours in asking specific questions such as the value of mitigated wetlands (Pechmann et al., 2001; Balcombe et al., 2005; Porej and Hetherington, 2005; Shulse et al., 2010) or the success of wetlands created specifically to facilitate amphibian breeding (Vasconcelos and Calhoun, 2004, 2006). Our study differs from these in that most basins sampled (we estimate about $85-90 \%$ based on topography and method of restoration) were, prior to EuroAmerican settlement, wetlands (prairie potholes; Lannoo et al., 1994; Lannoo, 1996)-that is, most wetlands in our study were true restorations, not creations of wetlands where no wetlands were known to have occurred.

An additional consideration in the success of these wetlands in attracting amphibians is that at the same time these wetlands were restored, the upland matrix surrounding these wetlands was converted from agriculture to grassland (smooth brome in older restorations, native ecotype prairie grass and forb species in more recent efforts). An upland matrix consisting of agricultural fields would have likely provided considerable landscape resistance to amphibian movements (Semlitsch, 2000; Babbitt et al., 2009) and produced occupancy values much less than we found (Balas et al., 2012). Not only is ease of movement a requirement for the colonization of new habitats and re-colonization following droughts (Lannoo, 1998; Smith and Green, 2005), such connectivity is also critical in maintaining genetic relationships among amphibian populations (Vos and Stumpel, 1995; Halley et al., 1996; Lehtinen et al., 1999; Marsh and Trenham, 2001). In Okoboji, the ability of amphibians to use upland corridors to facilitate juvenile and adult movements was enhanced at the same time wetlands became available.

Sampling Methods - The goal of our study was to explore amphibian colonization of wetlands restored for purposes other than amphibian conservation across a broad region. We had a small crew (two people); therefore we employed the recently developed technique of removal sampling (MacKenzie and Royle, 2005). Had we not used removal sampling and instead set traps in each of our wetlands for four days (one day for the initial placement and three subsequent days of sampling), we would have risked adopting a sampling period that extended beyond the timing of Northern Leopard Frog metamorphosis-that is, we risked sampling wetlands for tadpoles after tadpoles had metamorphosed and juveniles dispersed. For example, if we had sampled 10 wetlands every four days, it would have taken us 48 days, essentially seven weeks, to sample 118 wetlands. Beginning on 5 June, our sampling would have taken us into the last week in July, about two weeks beyond the typical time of metamorphosis of Northern Leopard Frogs in this region (Lannoo et al., 1994; Lannoo, 1996).

\section{CONCLUSIONS}

While most wetland restorations are not planned and executed with amphibians in mind (Lehtinen and Galatowitsch, 2001; Petranka et al., 2007; Lesbarrères et al., 2010; Lannoo, 2012a), we demonstrate here that in the Prairie Pothole Region of North America, such projects can increase habitat for pond-breeding frog and salamander species. Collectively, wetland restorations in Okoboji have established over 120 breeding populations of native amphibians over the past 30 years. We also show that the negative association found between amphibian abundance and urban/agricultural landscapes (Knutson et al., 1999) is reversed following landscape restorations-most of the $97 \mathrm{~km}^{2}$ of grassland and upland habitat comprising our study areas had previously been agricultural fields. We also show that landscape restorations can increase habitat for non-native American Bullfrogs and fishes, whose presence in wetlands may, in turn, limit populations of native tiger salamanders and leopard frogs (Tables 1 and 2).

To conserve amphibians, biologists must not only use an amphibian-centered conservation approach, but also employ the perspective of amphibians as critical components of important ecosystems (Bishop et al., 2012; Lannoo, 2012a; Mushet et al., 2012a, b). The wetland restorations of Okoboji offer an example of this phenomenon. Planned and carried out without amphibian populations as the major focus, the jointly sponsored USFWS/Iowa DNR wetland restorations produced by the Iowa Great Lakes Watershed Management Plan have at least partially offset Okoboji's historic native amphibian declines. Our work also indicates that strategies may be employed within these newly created basins to improve conditions for native amphibians. Periodic wetland drawdowns or the construction of fish barriers in key locations, for example, may be a way to set back fish populations in some locations (Lannoo, 1998). American Bullfrogs can be controlled with seining or wetland drawdowns in late summer to early fall (Galatowitsch and van der Valk, 1994). It is important for amphibian conservation biologists to remain engaged as species management plans are developed for these wetlands.

\section{ACKNOWLEDGEMENTS}

We thank Chet Rzonca, Steve Hendrix, and Peter van der Linden for sponsoring this research, Perry Williams and Patrick Cain for consulting on the statistics, and Susan Galatowitsch, Christopher Murphy, Peter Scott, Nathan Engbrecht, Jaimie Klemish, Andrew Hoffman, Jonathan Swan, and Susan Lannoo for proofreading earlier drafts of this manuscript. We also thank Mitch Dowell, Ben Moore, Chris Philby, and Jim Vojahosky for assisting with data collection; and Matt Fairchild and Seth Kaduce for assisting with logistics. We conducted this project after approval by and in accordance with Indiana State University's Animal Care and Use Committee (IACUC number 348676-1:ML) and the Iowa Department of Natural Resources' (DNR) Scientific Collection guidelines (Iowa DNR issued permit number SC-651). 


\section{LITERATURE CITED}

Adams, M. J., C. A. Pearl, S. Galvan, and B. McCreary. 2011. Non-native species impacts on pond occupancy by an anuran. Journal of Wildlife Management 75:30-35.

Alroy, J. 2015. Current extinction rates of reptiles and amphibians. Proceedings of the National Academy of Sciences 112:13003-13008. doi:10.1073/ pnas. 1508681112.

AmphibiaWeb. 2015. AmphibiaWeb Database. http:// amphibiaweb.org/amphibian/speciesnums.html (accessed 1 September 2015).

Anonymous. 1906. Frogs. OPA Bulletin 2:5.

Babbitt, K. J., M. J. Baber, D. L. Childers, and D. Hocking. 2009. Influence of agricultural upland habitat type on larval anuran assemblages in seasonally inundated wetlands. Wetlands 29:294-301.

Balas, C. J., N. H. Euliss Jr., and D. M. Mushet. 2012. Influence of conservation programs on amphibians using seasonal wetlands in the Prairie Pothole Region. Wetlands 32:333-345.

Balcombe, C. K., J. T. Anderson, R. H. Fortney, and W. S. Kordek. 2005. Wildlife use of mitigation and reference wetlands in West Virginia. Ecological Engineering 25:85-99.

Barrett, W. 1964. Frogging in Iowa. Annals of Iowa 37:362-365.

Bishop, P.J., A. Angulo, J. P. Lewis, R. D. Moore, G. B. Rabb, and J. Garcia Moreno. The Amphibian Extinction Crisis-what will it take to put the action into the Amphibian Conservation Action Plan? SAPIENS 5.2. http://sapiens.revues.org/1406 (accessed 29 January 2013).

Bradford, D. F. 1989. Allotopic distribution of native frogs and introduced fishes in high Sierra Nevada lakes of California: Implication of the negative effect of fish distribution. Copeia 1989:775-778.

Burnham, K. P., and D. R. Anderson. 2002. Model Selection and Multi-model Inference: A Practical Information-Theoretic Approach, Second Edition. Springer, New York.

Casper, G. S., and R. Hendricks. 2005. American Bullfrog: Rana catesbeiana. In: M. J. Lannoo (ed.) Amphibian Declines: The Conservation Status of United States Species, pp. 540-546. University of California Press, Berkeley.

Collins, J. P., and M. L. Crump. 2009. Extinction in Our Times: Global Amphibian Decline. Oxford University Press, New York.

Constantino, B. J., R. L. Schooley, and C. A. Phillips. 2011. Spatial connectivity moderates the effect of predatory fish on salamander metapopulation dynamics. Ecosphere 2: doi:10.1890/ES11-00111.1.

Dodd, C. K. Jr. 2010. Amphibian Ecology and Conservation: A Handbook of Techniques. Oxford University Press, New York.

Donovan, T. M., and J. Hines. 2007. Exercises in occupancy modeling and estimation. http://www.uvm. edu/envnr/vtcfwru/spreadsheets/occupancy.htm (accessed 15 September 2014).

ESRI. 2011. ArcGIS Desktop: Release 10. Environmental Systems Research Institute, Redlands, California.

Evelsizer, V., and J. L. Johnson. 2010. Wetland Action Plan for Iowa: Iowa Geological and Water Survey Special Report. Iowa Department of Natural Resources No. 4.

Evenson, E. J., and K. C. Kruse. 1982. Effects of a diet of bullfrog larvae on the growth of largemouth bass.
Progressive Fish-Culturist 44:44-46.

Galatowitsch, S. M., and A. G. van der Valk. 1994. Restoring Prairie Wetlands: An Ecological Approach. Iowa State University Press, Ames.

Gascon, C., J. P. Collins, D. R. Church, J. E. McKay, and J. R. Mendelson III. 2007 Amphibian Conservation Action Plan. IUCN/SSC Amphibian Specialist Group, Cambridge.http://www.amphibianark.org/pdf/ ACAP.pdf (accessed 3 March 2014).

Halley, J. M., R. S. Oldham, and J. W. Arntzen. 1996. Predicting the persistence of amphibian populations with the help of a spatial model. Journal of Applied Ecology 33:455-470.

Hayes, M. P., and M. R. Jennings. 1986. Decline of ranid frog species in western North America: Are bullfrogs (Rana catesbeiana) responsible? Journal of Herpetology 20:490-509.

Hecnar, S. J., and R. T. M'Closkey. 1997. The effects of predatory fish on amphibian species richness and distribution. Biological Conservation 79:123-131.

Herwig, B. R., L. W. Schroeder, K. D. Zimmer, M. A. Hanson, D. F. Staples, R. G. Wright, and J. A. Younk. 2013. Fish influences on amphibian presence and abundance in prairie and parkland landscapes of Minnesota, USA. Journal of Herpetology 47:489497.

Hines, J., and D. MacKenzie. 2013. Program PRESENCE: Version 5.5. United States Geological Survey. http:// www.mbr-pwrc.usgs.gov/software/presence.html (accessed 15 November 2013).

Iowa [DNR] Department of Natural Resources. 2014. Public Wildlife Management Areas. http://www.iowadrn.gov (accessed 28 February 2014).

Joseph, M. B., J. Piovia-Scott, S. P. Lawler, and K. L. Pope. 2010. Indirect effects of introduced trout on Cascades Frogs (Rana cascadae) via shared aquatic prey. Freshwater Biology 56:828-838.

Knapp, R. A., and K. R. Matthews. 2000. Non-native fish introductions and the decline of the Mountain Yellow-Legged Frog from within protected areas. Conservation Biology 14:428-438.

Knutson, M. G., J. R. Sauer, D. A. Olsen, M. J. Mossman, L. M. Hemesath, and M. J. Lannoo. 1999. Effects of landscape composition and wetland fragmentation on frog and toad abundance and species richness in Iowa and Wisconsin, USA. Conservation Biology 13:1437-1446.

Kolozsvary, M. B., and R. K. Swihart. 1999. Habitat fragmentation and the distribution of amphibians: Patch and landscape correlates in farmland. Canadian Journal of Zoology 77:1288-1299.

Korfel, C. A., W. J. Mitsch, T. E. Hetherington, and J. J. Mack. 2010. Hydrology, physiochemistry, and amphibians in natural and created vernal pool wetlands. Restoration Ecology 18:843-854.

Lannoo, M. J. 1996. Okoboji Wetlands: A Lesson in Natural History. University of Iowa Press, Ames.

Lannoo, M. J. 1998. Amphibian conservation and wetland management in the Upper Midwest: A catch 22 for the Cricket Frog? In: M. J. Lannoo (ed.) The Status and Conservation of Midwestern Amphibians, pp. 330-339. University of Iowa Press, Iowa City.

Lannoo, M. J. 2012a. A perspective on amphibian conservation in the United States. Alytes 29:133-144.

Lannoo, M. J. 2012b. The Iowa Lakeside Laboratory: A Century of Discovering the Nature of Nature. University of Iowa Press, Iowa City.

Lannoo, M. J., and M. D. Bachmann. 1984. Aspects of 
cannibalistic morphs in a population of Ambystoma t. tigrinum larvae. American Midland Naturalist 112:103-109.

Lannoo, M. J., K. Lang, T. Waltz, and G. S. Phillips. 1994. An altered amphibian assemblage: Dickinson County, Iowa, 70 years after Frank Blanchard's survey. American Midland Naturalist 131:311-319.

Lehtinen, R. M., and S. M. Galatowitsch. 2001. Colonization of restored wetlands by amphibians in Minnesota. American Midland Naturalist 145:388-396.

Lehtinen, R. M., S. M. Galatowitsch, and J. R. Tester. 1999. Consequences of habitat loss and fragmentation for wetland amphibian assemblages. Wetlands 19:1-12.

Lesbarrères, D., M. S. Fowler, A. Pagano, and T. Lodé. 2010. Recovery of anuran community diversity following habitat replacement. Journal of Applied Ecology 47:148-156.

Liner, A. E., L. L. Smith, S. W. Golladay, S. B. Castleberry, and J. W. Gibbons. 2008. Amphibian distributions within three types of isolated wetlands in southwest Georgia. American Midland Naturalist 160:69-81.

MacKenzie, D. I. 2006. Modeling the probability of resource use: The effect of, and dealing with, detecting a species imperfectly. Journal of Wildlife Management 70:367-374.

MacKenzie, D. I., and J. A. Royle. 2005. Designing occupancy studies: General advice and allocating survey effort. Journal of Applied Ecology 42:1105-1114.

MacKenzie, D. I., L. L. Bailey, and J. D. Nichols. 2004. Investigating species co-occurrence patterns when species are detected imperfectly. Journal of Animal Ecology 73:546-555.

MacKenzie, D. I., J. D. Nichols, G. B. Lachman, and S. Droege, J. A. Royle, C. A. Langtimm. 2002. Estimating site occupancy rates when detection probabilities are less than one. Ecology 83:2248-2255.

Mackenzie, D. I., J. D. Nichols, J. A. Royle, K. H. Pollock, L. L. Bailey, and J. E. Hines. 2006. Occupancy estimation and modeling: Inferring patterns and dynamics of species occurrence. Elsevier Academic Press, San Diego.

Mann, G. E. 1974. The Prairie Pothole Region-a zone of environmental opportunity. Naturalist 25:2-7.

Marsh, D. M., and P. C. Trenham. 2001. Metapopulation dynamics and amphibian conservation. Conservation Biology 15:40-49.

Mushet, D. M., N. H. Euliss Jr., and C. A. Stockwell. 2012a. A conceptual model to facilitate amphibian conservation in the northern Great Plains. Great Plains Research 22:45-58.

Mushet, D. M., N. H. Euliss Jr., and C. A. Stockwell. 2012b. Mapping anuran habitat suitability to estimate effects of grassland and wetland conservation programs. Copeia 2012:322-331.

Nicollet, J. N. 1843. Map of the Hydrographical Basin of the Upper Mississippi River. Blair and River Printers, Washington, D.C.

Norris, S. 2007. Ghosts in our midst: Coming to terms with amphibian extinctions. BioScience 57:311-316.

Pechmann, J. H. K., R. A. Estes, D. E. Scott, and J. W. Gibbons. 2001. Amphibian colonization and use of ponds created for trial mitigation of wetland loss. Wetlands 21:93-111.

Petranka, J. W., C. A. Kennedy, and S. S. Murray. 2003a. Responses of amphibians to restoration of a southern Appalachian wetland: A long-term analysis of community dynamics. Wetlands 23:1030-1042.

Petranka, J. W., S. S. Murray, and C. A. Kennedy. 2003b. Responses of amphibians to restoration of a southern Appalachian wetland: Perturbations confound post-restoration assessment. Wetlands 23:278-290.

Petranka, J. W., E. M. Harp, C. T. Holbrook, and J. A. Hamel. 2007. Long-term persistence of amphibian populations in a restored wetland complex. Biological Conservation 138:371-380.

Petranka, J. W., C. K. Smith, and A. F. Scott. 2004. Identifying the minimal geographic unit for monitoring pond-breeding amphibians. Ecological Applications 14:1065-1078.

Pope, K. L. 2008. Assessing changes in amphibian population dynamics following experimental manipulations of introduced fish. Conservation Biology 22:1572-1581.

Pope, K. L., L. Fahrig, and H. G. Merriam. 2000. Landscape complementation and metapopulation effects on leopard frog populations. Ecology 81:2498-2508.

Porej, D., and T. E. Hetherington. 2005. Designing wetlands for amphibians: The importance of predatory fish and shallow littoral zones in structuring of amphibian communities. Wetlands Ecology and Management 13:445-455.

Rosen, P. C., and C. R. Schwalbe. 1998. Using managed waters for conservation of threatened frogs. In: J. M. Feller, and D. S. Strouse (eds.) Environmental, Economic and Legal Issues Related to Rangeland Water Developments: Proceedings of a Symposium, pp. 180-202. Arizona State University College of Law, Tempe.

Rota, C. T., R. J. Fletcher Jr., J. M. Evans, and R. L. Hutto. 2011. Does accounting for imperfect detection improve species distribution models? Ecography 34:659-670.

Schwalbe, C. R., and P. C. Rosen. 1988. Preliminary report on effect of bullfrogs on wetland herpetofauna in southeastern Arizona. In: R. C. Szaro, K. E. Severson, and D. R. Patton (eds.) Proceedings of the Symposium on Management of Amphibians, Reptiles, and Small Mammals in North America, General Technical Report RM-166, pp. 166-173. United States Forest Service, Fort Collins.

Semlitsch, R. D. 2000. Principles for management of aquatic-breeding amphibians. Journal of Wildlife Management 64:615-631.

Shaffer, H. B., R. A. Alford, B. D. Woodward, S. J. Richards, R. G. Altig, and C. Gascon. 1994. Quantitative sampling of amphibian larvae. In: W. R. Heyer, M. A. Donnelly, R. W. McDiarmid, L. C. Hayek, and M. S. Foster (eds.) Measuring and Monitoring Biological Diversity: Standard Methods for Amphibians, pp. 130-141. Smithsonian Institution Scholarly Press, Washington, D.C.

Shulse, C. D., R. D. Semlitsch, K. M. Trauth, and A. D. Williams. 2010. Influences of design and landscape placement parameters on amphibian abundance in constructed wetlands. Wetlands 30:915-928.

Skelly, D. K., E. E. Werner, and S. A. Cortwright. 1999. Long-term distributional dynamics of a Michigan amphibian assemblage. Ecology 80:2326-2337.

Smith, M. A., and D. M. Green. 2005. Dispersal and the metapopulation paradigm in amphibian ecology and conservation: Are all amphibian populations metapopulations? Ecography 28:110-128.

Snodgrass, J. W., A. L. Bryan, and J. Burger. 2000. De- 
velopment of expectations of larval amphibian assemblage structure in southeastern depression wetlands. Ecological Applications 10:1219-1229.

SPSS. 2005. SPSS for Windows, Version 14.0. SPSS Inc., Chicago.

Stuart, S. N., J. S. Chanson, N. A. Cox, B. E. Young, A. S. L. Rodrigues, D. L. Fischman, and R. W. Waller. 2004. Status and trends of amphibian declines and extinctions worldwide. Science 306:1783-1786.

Templeton, A. R., E. Routman, and C. A. Phillips. 1995. Separating population structure from population history: A cladistic analysis of the geographical distribution of mitochondrial DNA haplotypes in the tiger salamander, Ambystoma tigrinum. Genetics 140:767-782.

van der Valk, A. G. 2005. The prairie potholes of North America. In: L. H. Fraser, and P. A. Keddy (eds.) The World's Largest Wetlands: Ecology and Conservation, pp. 393-423. Cambridge University Press, Cambridge.

Vasconcelos, D., and A. J. K. Calhoun. 2004. Movement patterns of adult and juvenile Rana sylvatica (LeConte) and Ambystoma maculatum (Shaw) in three restored seasonal pools in Maine. Journal of Herpe- tology 38:551-561.

Vasconcelos, D., and A. J. K. Calhoun. 2006. Monitoring created seasonal pools for functional success: A six-year case study of amphibian responses, Sears Island, Maine, USA. Wetlands 26:992-1003.

Vos, C. C., and A. H. P. Stumpel. 1995. Comparison of habitat-isolation parameters in relation to fragmented distribution patterns in the treefrog (Hyla arborea). Landscape Ecology 11:203-214.

Wake, D. B., and V. T. Vredenburg. 2008. Are we in the midst of the sixth mass extinction? A view from the world of amphibians. Proceedings of the National Academy of Sciences of the United States of America 105: 11466-11473.

Walston, L. J., and S. J. Mullin. 2007. Responses of a pond-breeding amphibian community to the experimental removal of predatory fish. American Midland Naturalist 157:63-73.

Weller, J. D. 1995. Restoration of a south Florida forested wetland. Ecological Engineering 5:143-151.

Zimmer, K. D., M. A. Hanson, and M. G. Butler. 2002. Effects of fathead minnows and restoration on prairie wetland ecosystems. Freshwater Biology 47:20712086. 